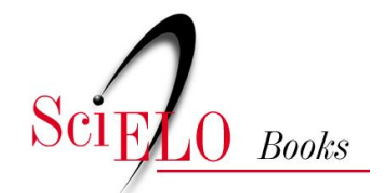

\title{
I. Apanhado histórico do povoamento e seus aspectos econômicos e políticos
}

\author{
Fernando Henrique Cardoso \\ Geraldo Müller
}

\section{SciELO Books / SciELO Livros / SciELO Libros}

CARDOSO, FH., and MÜLLER, G. Amazônia: expansão do capitalismo [online]. Rio de Janeiro: Centro Edelstein de Pesquisas Sociais, 2008. pp. 10-28. Apanhado histórico do povoamento e seus aspectos econômicos e políticos. ISBN: 978-85-99662-73-1. Available from SciELO Books $<\underline{\text { http://books.scielo.org }>\text {. }}$

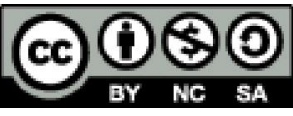

All the contents of this chapter, except where otherwise noted, is licensed under a Creative Commons Attribution-Non Commercial-ShareAlike 3.0 Unported.

Todo o conteúdo deste capítulo, exceto quando houver ressalva, é publicado sob a licença Creative Commons Atribuição Uso Não Comercial - Partilha nos Mesmos Termos 3.0 Não adaptada.

Todo el contenido de este capítulo, excepto donde se indique lo contrario, está bajo licencia de la licencia Creative Commons Reconocimento-NoComercial-CompartirIgual 3.0 Unported. 


\section{Apanhado histórico do povoamento e seus aspectos econômicos e políticos}

\section{Os devassamentos}

A partir dos anos 70 deste século, o mundo amazônico principiou a passar pelo quarto e, pode-se asseverar, último devassamento, impulsionado pela expansão capitalista. Último no sentido de penetração territorial, de propriedade das terras, minas e florestas, de organização econômica política da área. Mas trata-se de um começo.

O primeiro devassamento foi o da floresta tropical situada ao longo dos rios, furos, lagos e canais navegáveis. Buscavam-se as drogas do sertão, utilizáveis na alimentação, condimentação, construção naval e na farmacopéia da Europa ocidental.

Mas o histórico devassamento ocorreu entre as últimas décadas do século passado e as duas primeiras do atual, quando a Europa e os Estados Unidos industriais requeriam volumes maciços de borracha para a confecção de inúmeros objetos, desde os de uso doméstico até pneus para bicicletas, automóveis, material bélico e de construção naval. Foi o ciclo da borracha.

A partir dos anos 20/30 deste século tem início a invasão das frentes pioneiras agropecuárias e mineral, que penetram através dos enormes vãos das organizações extrativas de látex e de castanha. Ao lado dos empregados semiescravizados dessas organizações, aparecem sitiantes, fazendeiros, novos empregados e garimpeiros.

Durante os anos 60, com o início da abertura de estradas para a Amazônia e ligações internas à região, intensifica-se sobremaneira a penetração das frentes pioneiras; agora não mais oriundas apenas do nordeste e do Maranhão mas também do sul, via Belém-Brasília, e, por caminhos naturais, via Mato Grosso para Rondônia e Acre e sudoeste do Amazonas. Já nesta década começam a surgir as grandes organizações empresariais para a exploração do manganês e das terras férteis do Pará.

A possibilidade de grandes ocorrências de óleo, de aproveitamento industrial das fibras vegetais e de minérios, de utilização da área para "despressurizar" a situação social nordestina e para aproveitamento 
empresarial das matas, cerrados e campos, somada a sugestões e pressões internacionais, megalomaníacas umas ("grande lago", "pulmão do mundo"), interesseiras outras (extração e/ou beneficiamento direto de minerais e alimentos), levou o Estado brasileiro a tomar a si, como afirmação de sua soberania, a incumbência de um novo e ordenado devassamento amazônico. Mas ao fazer isto o Estado passou a avalizar o processo de acumulação na área, delegando às empresas sulinas tal propósito.

Deixando para a segunda parte deste trabalho os aspectos mais recentes que envolvem a ação governamental relativa à colonização, aos incentivos fiscais, à ação da empresa privada, à Transamazônica e à política rodoviária, enfim, aspectos que dizem respeito ao quarto devassamento do mundo amazônico, procurou-se retratar, na primeira parte, o processo de povoamento dessa área brasileira sob o prisma socioeconômico com ênfase nos aspectos demográficos.

Ao manejar as estatísticas disponíveis tendo em vista o processo de povoamento, buscou-se sempre trabalhar a equação produção-populaçãoforça de trabalho junto com os demais elementos econômico-políticos que com ela teceram a história.

\section{A área amazônica}

É uma tarefa difícil a de efetuar um corte de cunho territorial da chamada Amazônia, ainda mais quando se a olha pelo ângulo das estatísticas e das informações disponíveis. Em termos puramente geográficos, os limites da floresta amazônica em território brasileiro, tomando como ponto de partida o leste, principiam um pouco antes da Capital do Maranhão (São Luís); daí ela segue em direção ao sul, englobando três quartos da área desse Estado, afunda-se cada vez mais para sudoeste, incluindo o tipo norte de Goiás e um terço do norte matogrossense ${ }^{1}$. Esta área, se bem que menor, coincide, grosso modo, com a

\footnotetext{
${ }^{1}$ Descrição baseada no mapa sobre a floresta amazônica, in Grande Região norte, Antônio Teixeira Guerra, org., Cap. I, p. 12, IBGE, 1959.
}

Amazônia Legal ${ }^{2}$, algo em torno de cinco milhões de quilômetros quadrados, cerca de $59 \%$ do território nacional ${ }^{3}$.

Se bem que no sentido geográfico e no sentido econômicodemográfico a área mostre grande uniformidade, esta característica genérica apresenta nuanças de extrema importância. Observe-se, no entanto, que as informações disponíveis - por se limitarem em sua quase totalidade ao nível estadual - não permitem o estudo da área compreendida pela floresta amazônica ou pela Amazônia Legal. Por conseguinte, a área física abrangida como amazônica identifica-se, para fins estatísticos com a Região norte ${ }^{4}$, isto é, a área compreendida pelos Estados do Acre, Amazonas e Pará e pelos Territórios Federais do Amapá, Rondônia e Roraima; automaticamente, ficam excluídas nas análises censais as áreas amazônicas dos Estados de Goiás, Mato Grosso e Maranhão. Quanto a este último, cuja parcela maior de sua área integra a região amazônica, com exceção dos vales do Mearim e de Itapecuru, e cuja geografia e parte da economia constituem-se como espaço de transição entre a Região norte e a Nordeste, tentaremos tomar os dados estatísticos, notadamente de 1970/72, como elemento complementar e comparativo da análise.

As fontes utilizadas para o presente relatório são monografias e capítulos de livros pertinentes ao tema, estatísticas dos Censos Demográficos e do Recadastramento do INCRA de 1972.

\section{As drogas do sertão}

Em meados do século XVI, o açúcar propiciava já boas rendas à Coroa portuguesa, além de forte capacidade de negociação com outras nações européias emergentes interessadas na comercialização das especiarias. Nada mais justo do ponto de vista da Coroa do que preocuparse com a defesa do monopólio daquele produto. O que implicava em proteger todas as terras tropicais potencialmente produtoras. Em fins desse século, portugueses e espanhóis, juntos sob a União Ibérica (1580-1640),

\footnotetext{
${ }^{2}$ Definida pela Lei 1.806, de 06/01/1953, a mesma que criou a Superintendência do Plano de Valorização Econômica da Amazônia (SPVEA).

${ }^{3}$ Conforme o mapa da Região norte e Maranhão, segundo as microrregiões homogêneas em anexo.

${ }^{4}$ A Região norte totaliza $3581180 \mathrm{~km}^{2}$, isto é, cerca de $42 \%$ do território nacional.
} 
defenderam-se dos ataques que se faziam em toda a linha que desce das Antilhas ao nordeste brasileiro. Mesmo após a Restauração (1640), e com as concessões feitas à Holanda e Inglaterra em troca de aliança na luta contra a Espanha, a preocupação portuguesa manteve-se. Ampliou-se, na verdade. Criou-se o Conselho Ultramarino com o fito de controlar e "minimizar as brechas abertas ao uso de seu exclusivo colonial".

Nesse contexto de disputa pela posse de terras que comportassem um produto comercializável na Europa ou de terras que pudessem comportar sua produção, a atual Amazônia compunha a retaguarda econômica da metrópole e integrava-se como peça da acumulação primitiva européia, ou seja, integrava-se como componente da expropriação que priva a grande massa do povo da terra e dos meios de vida e instrumentos de trabalho. Daí o caráter comercial e capitalista da colonização ${ }^{6}$.

O povoamento da Amazônia ocorre durante os séculos XVII e XVIII, quando os portugueses, a partir de Recife e Salvador, se deslocam para a região com a finalidade de afastar os concorrentes ingleses, holandeses e franceses que se apoderavam das "drogas do sertão" (canela, cravo, anil, cacau, raízes aromáticas, sementes oleaginosas, madeiras, salsaparrilha etc.). Desse movimento de defesa surgem São Luís do Maranhão, Belém do Pará, Macapá, no extremo norte, e Manaus, na confluência dos rios Negro e Amazonas. São núcleos fortificados aos quais vão-se reunindo aldeamentos indígenas e colonos que tentam pôr em prática as diretrizes do governo de Lisboa que visava a passar da coleta das drogas a seu cultivo e, assim, apossar-se efetivamente dessas áreas, originariamente (segundo o Tratado de Tordesilhas) pertencentes à Espanha. Esta foi uma linha de povoamento basicamente lastreada em uma ação militar em prol das terras potencialmente produtivas.

Uma outra linha tem origem no movimento de caça ao índio por parte dos colonos assentados no Maranhão. Necessitados de mão de obra para a produção de açúcar, fumo e outros produtos, esses colonos decidiram-se a escravizar o elemento nativo. Fustigados pelos jesuítas, perseguidores e

${ }^{5}$ NOVAIS, Fernando A., Estrutura e Dinâmica do Antigo Sistema Colonial: (Séculos XVIXVIII), São Paulo, CEBRAP, Caderno 17, 1974, p.26.

${ }^{6}$ Idem, parte sobre "O 'exclusivo' comercial," pp. 17 a 36. A disputa por aquelas terras integrava a esfera da luta intermetrópoles. defensores dos índios, foram penetrando na floresta amazônica, através das vias fluviais e matas rasas, descobrindo assim suas potencialidades, as especiarias.

Da má sorte dos colonos no Maranhão, em virtude da queda do mercado açucareiro e de outros produtos (1650/70) e da necessidade de lutar pela mão de obra indígena frente a reação dos jesuítas: resultou uma enorme expansão territorial durante o século XVII até aos meados do século seguinte.

O colono não conseguiu organizar o índio nos moldes escravistas; no entanto, usufruiu de seu trabalho por intermédio da sagacidade jesuítica. Se de início os inacianos atuaram em defesa do indígena, buscaram depois formas adequadas de convivência (obtinham a mão de obra dessa gente mediante doação de quinquilharias) e acabaram na exploração servil dessa mão de obra ${ }^{7}$.

A desarticulação da forma tribal das relações sociais em proveito mercantil através da injeção de artigos europeus, "cujo fornecimento posterior era condicionado à sua (indígena) participação nas atividades produtivas", foi condição para o devassamento da floresta tropical ao longo dos rios, furos, lagos e canais e a exploração das drogas do sertão. ${ }^{8}$ Os núcleos militares e coloniais e as missões, baseados na exploração da mão de obra indígena, são as primeiras manifestações de povoamento na Amazônia.

A economia brasileira, em seu conjunto, apresentava-se, nos meados do século XVIII, como uma constelação de sistemas tenuamente articulados entre si: a faixa açucareira, a região mineira e o Maranhão. Esses sistemas interligavam-se através da extensa hinterlândia pecuária, mas de modo fluido e impreciso. No último quartel desse século, o único sistema que apresentou efetiva prosperidade foi o do Maranhão, que estivera estagnado desde meados do século anterior, devido à já mencionada desorganização dos mercados açucareiros e de outros produtos. Na Amazônia, então com a denominação de Grão-Pará, alguma diminuta influência da prosperidade maranhense será sentida; também aqui as atividades entraram em

${ }^{7}$ A propósito da expansão territorial desse período e da relação dos jesuítas, colonos e indígenas, consulte-se FURTADO, Celso, Formação Econômica do Brasil, $3^{\mathrm{a}}$ ed., Cap. 12 Editora Fundo de Cultura, Rio de Janeiro, 1961

${ }^{8}$ Sobre a desarticulação aludida, as relações entre aborígines, colonizadores e missionários, bem como a situação atual (1950/60) do indígena na Amazônia, veja-se RIBEIRO, Darcy, $O$ Índios e a Civilização, pp. 21-47, Civilização Brasileira, Rio de Janeiro, 1970 
decadência desde meados do século XVIII devido à desorganização do sistema jesuítico, causada pela ação de Pombal ${ }^{9}$.

A mencionada prosperidade ocorreu num panorama mundial muito particular - revolução industrial inglesa, guerra de independência norteamericana, Guerra dos Sete Anos - que encontrou a Companhia Geral do Grão-Pará e Maranhão em plena atividade. A partir de 1750, Pombal intenta apressar o povoamento da Amazônia. Decreta leis que isentam os colonizadores de impostos régios, que concedem sesmarias como prêmio, que distribuem gratuitamente instrumentos agrícolas. Em 1755 institui a Companhia Geral do Grão-Pará e Maranhão para coordenar e aplicar o ambicioso projeto. No entanto, a prosperidade alcançada principalmente em território maranhense - foi efêmera, pois apoiava-se em condições anormais do mercado mundial de algodão e arroz. Em 1778, a Companhia Geral é extinta. No Grão-Pará, o volume da produção extrativa, nessa época de prosperidade, foi sempre maior do que o volume da produção cultivada. Dessa feita, no início do século XIX, a agricultura praticamente restringiase à subsistência ${ }^{10}$.

Como reflexo desse período de prosperidade, que carreou para a área grande contingente de escravos negros, o Maranhão contava, em 1808, com mais de 120 mil habitantes. O Grão-Pará não alcançava a cifra dos cem mil. Demograficamente preponderou o incremento vegetativo, basicamente da população indígena aldeada mais aquela atraída à civilização que se implantava. No final dos oitocentos, "a população civilizada regional (não ultrapassava) os 100.000 habitantes". ${ }^{11}$ Outra fonte ${ }^{12}$ assinala para 1808 uma

\footnotetext{
${ }^{9}$ Consulte-se FURTADO, Celso, op. cit., Cap. 16, "O Maranhão e a Falsa Euforia do Fim da Época Colonial".

${ }^{10}$ Há autores que dão maior importância à época anterior ao ciclo da borracha; afirmam que próximo às cidades e vilas havia inúmeros sítios, "significativas células do ambiente rural" produzindo gado, café, cana e cacau. Ver Grande Região norte, op. cit., Introdução e Cap. XIV. Se aceitarmos que a economia da área era praticamente fechada, tornar-se-á difícil subscrever a hipótese da importância da organização social dessa época. Veja-se, por exemplo, o que diz do Pará no último quartel do séc. XVIII Celso Furtado, em Formação Econômica do Brasil, Cap. 16. Veja-se, ainda, sobre esse aspecto, principalmente sobre a Companhia Geral, o trabalho de Manuel N. Dias, Fomento Ultramarino e Mercantilismo: A Companhia Geral do Grão-Pará e Maranhão, in Revista de História, $\mathrm{n}^{\circ} . .64$, out./dez., 1965, e $\mathrm{n}^{\circ} . .84$, out./dez., 1970, São Paulo.

11 TUPIASSU, Amílcar Alves, O Processo Demográfico da Amazônia, Instituto do Desenvolvimento Econômico-Social do Pará, 1968, mimeo. Em nota, o autor cita "Síntese da
}

população de 97 mil pessoas. Assim, realmente, em torno de 1800, a Amazônia não alcança 100 mil habitantes; excetuam-se, é claro, as tribos não vinculadas ao sistema português de dominação.

\section{O ciclo da borracha}

Se o "ciclo" das drogas do sertão fez parte de uma economia que nasceu como uma reserva e participou como uma peça da pré-história do capital, a época da expansão do sistema capitalista em escala mundial, o ciclo da borracha nasce e se desenvolve tendo como objetivo baratear, via imposição de preços coloniais à borracha, o capital constante utilizado nos empreendimentos industriais das novas potências mundiais ${ }^{13}$.

A capacidade de comprimir os preços do produto - que no limite levará à quebra do processo extrativo mediante a produção inglesa na Ásia - residia, mais uma vez, na forma de trabalho compulsório. Os ganhos da intermediação comercial e financeira internas - realizados pelas casas aviadoras (comerciantes) - relacionavam-se ao curto espaço de tempo da volumosa demanda externa. Os altos preços pagos em Belém e Manaus refletiam o interesse externo em empresariar nacionais para o devassamento da floresta em busca do látex. Entre o trabalho e o produto obtidos mediante relações econômicas quase escravas e o financiamento e a comercialização realizados por capitais estrangeiros, situavam-se os ganhos dos empresários nacionais.

O controle da realização externa da borracha - ao Estado interessava captar os impostos sobre o volume exportado, ademais de estar voltado sobretudo para o café - configurava-se, praticamente, como um monopólio

História do Pará,” de Arthur César Ferreira Reis: “... nos últimos tempos coloniais, o Pará contava com 79.730 habitantes".

${ }_{12}$ Resumo Histórico dos Inquéritos Censitários Realizados no Brasil, IBGE, Rio de Janeiro, 1951 (Documentos Censitários, Série B, 4). Todos os dados populacionais, que aparecerão daqui por diante, salvo indicação em contrário, foram extraídos de "Redistribuição Regional e Rural-Urbana da População Brasileira," LOPES, Juarez Rubens Brandão e PATARRA, Neide Lopes, CEBRAP, 1974, Tabela I (mimeo.).

13 A respeito do sentido histórico da economia durante a República Velha e da relação fundamental dessa com o imperialismo inglês, que se traduzia na intermediação comercial e financeira, consulte-se o trabalho de OLIVEIRA, Francisco de, A Emergência do Modo de Produção de Mercadorias: uma Interpretação Teórica da Economia da República Velha no Brasil, Bóris Fausto, org., in História Geral da Civilização Brasileira, Tomo III, O Brasil Republicano, 1. Estrutura de Poder e Economia (1889-1930), São Paulo, Difel, 1975. 
do excedente, com fortes semelhanças com o "exclusivo" comercial português do tempo das drogas do sertão.

Dada a forma de trabalho adotada - num contexto de um ciclo econômico extrativo de relativamente curta duração, que apenas produziu uma pequena camada social que vivia da intermediação -, não ocorreram na Amazônia as profundas alterações de que foi palco o centro-sul do país, com a produção de café baseada nas novas relações de produção de tipo salarial, das quais resultaram uma maior divisão social do trabalho e a expansão do mercado interno. Ocorreu, no entanto, uma modificação extraordinária no volume da população amazônica.

Em 1823, a atual Região norte contava com uma população em torno de 127 mil que, em 1872, passa a ser de quase 340 mil; em 1900, soma quase 700 mil e, 20 anos mais tarde, algo mais de 1.400.000. Como se nota, o aumento a partir de 1872 foi sensível. Essa população, movida pelos interesses econômicos ligados à extração do látex, devassa a floresta tropical brasileira, incorpora um território de quase $200 \mathrm{mil} \mathrm{km}^{2}$ retirado da Bolívia, extermina parte da população indígena, miscigena-se parcialmente com eles e provoca o crescimento urbano de Belém e Manaus.

O extraordinário crescimento populacional resulta de dois processos fundamentais. Em que pesem as tentativas do governo de Londres de desenvolver-se o plantio das mudas da Hevea em suas colônias asiáticas (Ceilão e Malásia), os preços internacionais da borracha elevaram-se enormemente a partir dos anos 70 do século passado: de 45 libras esterlinas a tonelada, em média, na década de 1840/50, passam a 118 libras na década seguinte, atingem 182 libras no decênio 1870/80, alcançando 389 libras em 1900/1910. Tais preços são expressão da enorme demanda industrial, a relativamente curto prazo, sobre uma área natural potencialmente fornecedora do produto, já que as tentativas de plantio na Ásia não tiveram êxito.

Por outro lado, uma prolongada seca na região nordestina, entre 1877 e 1880, dizimou entre cem a duzentas mil pessoas e praticamente todo o rebanho da área, deixando um quadro de miséria acabrunhador. Ao mesmo tempo dificultou a reação dos grupos dominantes da região à emigração induzida (pela propaganda e incentivos oficiais) para os Estados amazônicos de algo como meio milhão de pessoas ${ }^{14}$.

A conjugação desses fatores responsáveis pelo maciço incremento da mão de obra levará a produção de borracha a saltar de suas modestas 3.700 toneladas anuais, em média, na década de 1850/60, para quase 35 mil, na década 1900/10. Tudo isso graças às levas de nordestinos, cujos custos de migração foram obtidos pelos seringalistas comerciantes a preços, em boa parte, subsidiados pelo poder público. Além disto, os migrantes eram obrigados a ressarcir o seringalista dos adiantamentos (instrumentos de trabalho, despesas de instalação e suprimento).

A disposição desta mão de obra não só resolveu o problema de sua escassez relativa - pois ela era até então quase inexistente na área amazônica - como reforçou a tendência ao estabelecimento de relações de trabalho compulsório. Estas tanto se baseavam na utilização da única força de trabalho disponível na área - as populações indígenas - que passaram a ser "compulsoriamente aliciadas para a produção da borracha e para os trabalhos ligados à navegação fluvial", ${ }_{15}$ como na coação que foi exercida sobre a população nordestina para que ela se ajustasse ao trabalho no seringal, onde o "barracão" e os capangas reiteravam ao trabalhador sua sina. Se notarmos que as condições técnicas de produção para a obtenção da borracha supunham baixa concentração dos seringueiros nativos, baixa produtividade do trabalho além dos perigos oferecidos pela mata; que a produção se fazia em condições da volumosa demanda a curto prazo; e que tudo se organizava ao sabor da audácia individual, nessas condições era praticamente impensável uma mudança nas relações sociais de produção semelhantemente ao ocorrido na economia cafeeira do sul quando, através da importação de imigrantes e do início do estabelecimento de relações salariais, os fazendeiros puderam fazer face ao fim da escravidão. $\mathrm{Na}$ Amazônia a abertura da área à exploração da borracha deu-se depois da extinção da escravidão (o tráfico terminara em 1850 e o preço do escravo nacional subira muito, graças à demanda do centro-sul) e sem que fosse possível - pelas condições apontadas - estabelecer o sistema de trabalho

\footnotetext{
${ }^{14}$ Para maiores detalhes sobre a emigração nordestina para a Amazônia, veja-se o Cap. 23 da obra de FURTADO, Celso "O Problema da Mão de obra: Transumância Amazônica".
}

${ }^{15}$ RIBEIRO, Darcy, op. cit., p. 24 
livre assalariado. Foi nestas condições que se expandiram as relações de produção quase escravas.

Uma vez explicado o processo de povoamento à época do ciclo da borracha, convém observar mais acuradamente os aspectos demográficos.

Como vimos, em 1870 a Amazônia contava com uma população pouco superior a 300 mil habitantes e, 50 anos depois, avultava a mais de 1400 mil. Por outro lado, desde 1827, data do primeiro registro de exportação da borracha (31 t), a produção e a exportação conhecem aumentos contínuos. Pelos meados do século a produção monta a umas 1000 t, em 1870, 8 mil t. No decênio 1891-1900 atinge uma média de 21,4 mil $\mathrm{t}$ anuais e o primeiro decênio do século XX, 34,5 mil; cai para 32,8 mil e depois para 20,2 mil anuais, nos decênios seguintes. Em 1912 a produção alcança seu ponto máximo, com 42 mil t. Dai por diante é o declínio, afirma Caio Prado Jr. ${ }^{16}$.

O importante para nosso estudo é a conclusão de Celso Furtado que relaciona o aumento da produção com o da população: "esse aumento da produção deveu-se exclusivamente ao influxo de mão de obra, pois os métodos de produção em nada se modificaram"17.

A relação entre acréscimos periódicos da população amazônica e a participação da produção brasileira de borracha na produção mundial parece um fato insofismável. Senão, vejamos. Em 1878, cem por cento da produção mundial do produto eram brasileiros. Em 1890 a participação decresce para 90\%. Nos quatro quinquênios consecutivos a partir de 1900, isto é, de 1900 a 1919, a participação cai de 70\% para 53\%, 34\%, 12\%: no quinquênio $1925-29$, mal atinge $2 \%{ }^{18}$. A inserção no contexto mundial é fundamental. A exploração da borracha irá passar por três fases: a primeira, com caráter de emergência; a segunda, com produção em bases racionais, e a terceira, a partir dos anos 40, com a substituição progressiva do produto natural pelo sintético. Interessam-nos aqui as duas primeiras. Pois bem, "a primeira fase da economia da borracha se desenvolve totalmente na região

\footnotetext{
${ }^{16}$ PRADO JÚNIOR, Caio, História Econômica do Brasil, Brasiliense, 1a ${ }^{a}$ ed., p. 239.

${ }^{17}$ Op. cit., p. 157.

${ }^{18}$ Dados tomados de CARONE, Edgard, A República Velha (Instituições e Classes Sociais), Difel, São Paulo, $2^{\mathrm{a}}$. ed., rev. e aumentada, 1972, pp. 64-65.
}

amazônica $^{19}$; a segunda, a partir de 1915/ /19, no sudeste da Ásia. A queda na participação mundial terá efeitos econômicos enormes, na região, mas também efeitos demográficos.

Os acréscimos populacionais praticamente refletem essa participação. Tomando 1872 = 100 (338 mil habitantes) obtemos para o período 1872/1900 um acréscimo de 40\%; no decênio seguinte o acréscimo alcança 47\%! Entre 1900 e 1920, 107\% ;20 podemos supor, como Celso Furtado, que parcela bem maior tenha ocorrido no primeiro decênio. Já entre 1920 e 1940, o acréscimo não ultrapassa $0,2 \%$, quer dizer, há uma estagnação demográfica.

Tudo leva a crer que no ciclo da borracha a expansão populacional firma-se na imigração, o que, no entanto, não é ponto pacífico entre os estudiosos $^{21}$.

Admitindo um crescimento vegetativo anual de $1 \%$, considerando que "as condições de salubridade são reconhecidamente precárias na região", Celso Furtado calcula que o influxo externo alcançou $260 \mathrm{mil}$ pessoas no período 1872 e 1900, das quais cerca de 200 mil corresponderiam ao último decênio; com base nos censos e ainda na admissão de um crescimento vegetativo anual idêntico, conclui que entre 1900 e 1910 um volume igual ao anterior tenha chegado à região. "Resulta que a população deslocada para a região amazônica não seria inferior a meio milhão de pessoas", ${ }^{22}$ hipótese bastante plausível para explicar o sensacional pulo populacional de quase 340 mil em 1872 para mais de 1400 mil em 1920.

Tal acréscimo dificilmente pode ser atribuído, na sua maior parte, ao crescimento vegetativo da população residente na região em 1900, como parecem sugerir H. D. Graham e S. Buarque de Holanda Filho e até mesmo

\footnotetext{
${ }^{19}$ FURTADO, Celso, op. cit., p. 157.

${ }^{20}$ Não há censo para 1910

${ }^{21}$ Não se deve esquecer a incorporação dos indígenas à atividade coletora. Por exemplo, "os Tucuna foram engajados na economia da coleta do látex desde o momento em que os seringalistas se apropriaram de suas terras, em princípios do século. Os que habitavam os igarapés afluentes do rio Solimões - e que continuam a ser hoje a maioria - passaram automaticamente à condição de 'servos' de gleba dominados pelo 'regime de barracão', a saber pelo escambo compulsório”. OLIVEIRA. Roberto C. de. Povos Indígenas e Mudança Sóciocultural na Amazônia, Fundação Universidade de Brasília, 1973, p. 11.

${ }^{22}$ FURTADO, Celso, op. cit., p. 158.
} 
Tupiassu ${ }^{23}$. Pelos dois primeiros, através de cálculos dos saldos migratórios (dois métodos), ${ }^{24}$ constata-se que a população não teria crescido mais de 191200 imigrantes ( $1^{\circ}$ método) e de 144900 imigrantes. ( $2^{\circ}$ método), o que implica em que o restante populacional do aumento global viria do crescimento vegetativo. Dessa maneira, cerca de 500 mil pessoas teriam nascido na região, o que exigiria uma elevada taxa de crescimento vegetativo; hipótese difícil de sustentar se levarmos em consideração a suposição realista de Furtado sobre as altas taxas de mortalidade e de que boa parcela dos imigrantes não levava a família ${ }^{25}$.

Em 1920, como vimos, a participação da borracha brasileira na produção mundial anda por volta dos $10 \%$ e, um decênio após, em torno de 2\%. A população entre 1920 e 1940 estagna, o que indica emigração, calculada por Graham e Buarque em 191,2 mil ( $1^{\circ}$ modelo) e 190,5 mil ( $2^{\circ}$ modelo), a maioria oriunda do Pará $(150 \mathrm{mil})$, o que permite pensar que tal população não estava diretamente comprometida com a produção de

${ }^{23}$ GRAHAM, H. Douglas e HOLANDA FILHO, S. B., Migration, Regional and Urban Growth and Development in Brazil, São Paulo, IPE, 1971. apud Redistribuição Regional, etc., de LOPES, J. R. B. e PATARRA, Neide Lopes, já citado, Tabelas 6 e 7. Tupiassu, op. cit., caracteriza o período 1850-1920 como fundado na imigração, "embora seja lícito supor que os incrementos vegetativos também se fizeram a taxas elevadas, pois sem isso dificilmente se explicaria a grande expansão populacional havida.”. (p. 9).

24 "Os autores utilizaram, para estimar os dados migratórios, tanto taxas de sobrevivência globais (para todo o país) aplicadas a cada Estado, como também outro método (denominado 'forward survival ratios') em que projetam, de um censo a outro, grupos de sexo-idade de cada Estado, com a utilização de uma mesma série de taxas especificas de mortalidade. As estimativas obtidas pelos dois métodos são diferentes; diferenças, entretanto, que não são de monta a invalidar as conclusões que delas podem ser retiradas". Apud Redistribuição Regional, etc., de LOPES, Juarez Rubens Brandão e PATARRA, Neide Lopes, nota 14. A uniformização das taxas talvez seja responsável pela conclusão que os dados carregam consigo no caso do ciclo da borracha.

${ }^{25} \mathrm{O}$ caboclo amazônico e os primeiros retirantes nordestinos viviam com suas famílias, "mas no período do rush da borracha o homem em geral vinha só. Neste caso, a mulher tornou-se objeto cobiçado. Encomendavam-se mulheres aos patrões e estes às casas aviadoras como encomendavam-se gêneros alimentícios e, como verdadeiras mercadorias, entravam nas contas escrituradas pelos guarda-livros". PRADO, Maria L. C. e CAPELATO, Maria H. R., em seu trabalho "A Borracha na Economia Brasileira da Primeira República," in O Brasil Republicano, História Geral da Civilização Brasileira, Difel, São Paulo, 1975. Darcy Ribeiro, na obra já citada, p. 27, observa que uma das características da "onda invasora que a faz lançarse contra os índios é ser composta principalmente de homens que, uma vez dispersos pelos seringais, só podiam satisfazer suas necessidades sexuais ou conquistar uma companheira) tomando-a aos índios" borracha (uma vez que esta se situava no Estado do Amazonas, estando no Acre a maior concentração de seringueiras), mas nos outros setores urbanos dependentes do fluxo de renda daquele setor.

A Região norte, dos anos 20 para a frente, torna-se uma área de emigração, característica que irá perdurar, grosso modo, até 60, quando então atuará (1960/70) como área receptora.

\section{Balanço do ciclo da borracha}

Um balanço desse período permite captar quatro características que ainda hoje marcam a região.

A primeira característica é o chamado "sistema de aviamento", que se desenvolveu na Amazônia. A atividade econômica extrativo-predatória no interior das matas; a distância entre as seringueiras, o que exigia longas caminhadas; as condições impostas pelo proprietário, não permitindo roçado (geralmente, mandioca); a necessidade de mão de obra para aumentar a produção; o pagamento obrigatório dos trabalhadores aos patrões do custo da viagem do nordeste à Amazônia, dos instrumentos de trabalho, das provisões, enfim, o regime de trabalho e o padrão de vida dos seringueiros baseavam-se no endividamento prévio e posterior, isto é, no endividamento reiterado, o que colocou o trabalhador nas mãos do proprietário comerciante. Por sua vez, este dependia dos fornecimentos e da compra das bolas de borracha feitas por um comerciante maior. Formavase, assim, uma cadeia que atingia as grandes casas exportadoras de Manaus e Belém. Este esquema de funcionamento da economia é que se denomina aviamento. Em outras palavras, o fornecimento de mercadorias (instrumentos de trabalho e bens de consumo) a crédito e o bombeamento da borracha para Manaus mas, principalmente, para Belém, e daí para o mercado internacional, geraram uma rede complexa e extensa de canais através dos quais respirava a economia. Tão logo a borracha se mostrou um empreendimento rendoso, capitais estrangeiros surgiram na boca do cofre, i.e., instalaram-se nas duas Capitais ${ }^{26}$. A Amazônia participou da

${ }^{26} \mathrm{O}$ aviamento é o resultado, ao mesmo tempo que o mecanismo pelo qual se reitera a "cadeia de dependências". Prado e Capelato observam que, "numa cadeia de dependências, a falta de capitais obrigou a casa aviadora a subordinar-se ao capital estrangeiro, o seringalista a tornar-se devedor da casa aviadora e, num elo mais forte, o seringueiro a sujeitar-se ao seringalista". 
intermediação comercial e financeira externa, o que reiterou, durante o ciclo, a vocação extrativa predatória de uma camada de seringalistas comerciantes, cujos ganhos se esvaeceram num consumo conspícuo e improdutivo. A dinâmica dessa economia, em terras amazônicas, se operava pelo aviamento, mecanismo cuja importância ultrapassou o ciclo e, ainda hoje, pesa bastante no conjunto da economia.

Uma segunda característica da economia da borracha provém do processo de obtenção do produto e de sua circulação - é a existência de poucas cidades, mas grandes, fenômeno semelhante ao que ocorreu nas áreas mineradoras e pecuárias. A malha urbana é rarefeita mas com avolumados nódulos. Observe-se que, em 1890, a população dos municípios das duas grandes Capitais da região, Manaus e Belém, perfaz $18 \%$ da população total da Amazônia; em 1900, 21\%; e, em 1920, 28\%.26 ${ }^{27}$

Em terceiro lugar, convém assinalar que a população rural, a partir dos anos 20, oscila entre as atividades agrícolas (roçado de subsistência) e as de extração (borracha e castanha-do-pará). E uma população bastante sensível aos preços de mercado, da borracha e da castanha. ${ }^{28} \mathrm{~A}$ um aumento destes ocorre um deslocamento da população da agricultura para a coleta. Dispomos apenas de dados específicos para 1940 e $1950 .^{29}$

\begin{tabular}{|l|c|c|}
\hline Pessoal ocupado (RN) & 1940 & 1950 \\
\hline Na agricultura & $260 \mathrm{mil}$ & $240 \mathrm{mil}$ \\
\hline Na coleta (extração) & $120 \mathrm{mil}$ & $160 \mathrm{mil}$ \\
\hline
\end{tabular}

As informações atuais, 1940-70, permitem que se afirme que tal movimento pendular do uso da mão de obra persiste. Claro está que esse

PRADO, L. C. e CAPELATO, Maria H. R., "A Borracha na Economia Brasileira da Primeira República," in O Brasil Republicano, op. cit., p. 298.

${ }^{27}$ LOPES, Juarez Rubens Brandão e PATARRA, Neide Lopes, op. cit., Tabela 3.

${ }^{28}$ A reação sensível aos preços de mercado deve ser entendida dentro do sistema de aviamento; pode aparecer como obrigação direta de deslocar mão de obra para a borracha, bem como pode aparecer como possibilidade de a mão de obra saldar suas dívidas. Os diversos mecanismos que possibilitam dispor de mão de obra (barracão, pequeno roçado, adiantamentos monetários) atuam sobre ela, periodicamente, obrigando-a, para sua manutenção, a respeitar a demanda de braços nas atividades mercantis.

${ }_{29}^{2}$ Desenvolvimento Econômico da Amazônia, Banco da Amazônia S/A. (BASA), Est. da Universidade Federal do Pará, 1967, p. 145. movimento continua em um contexto que se diversifica, como se verá logo mais $^{30}$.

Por último, a quarta característica da região diz respeito a que se o ciclo da borracha pressupôs uma transferência de população de modo a dotar a Amazônia de uma massa de mão de obra capaz de fornecer as magnitudes do produto anteriormente citadas, sua organização social não permitiu que houvesse uma divisão social do trabalho capaz de propiciar a formação de um mercado interno. Isso aconteceu basicamente devido à forma compulsória que assumiu a exploração daquela mão de obra, ao lado da necessidade de aproveitar toda e qualquer mão de obra na monocultura extrativa, a tal ponto que até a diminuta lavoura local entrou em colapso. Atualmente, mesmo com o ingresso das grandes empresas nacionais e estrangeiras, esse modo de exploração não se alterou - se bem que existam indícios de mudança nas empresas mineradoras.

Em síntese, o declínio da participação brasileira na produção mundial da borracha e o declínio da produção nacional (de umas 20 mil t em 1920, cai para 10 mil em 1930) ocasionaram, como vimos, a estagnação demográfica - mas, não foi só isso; podemos inferir que ocorreu também uma regressão da economia mercantil da borracha e das atividades dela dependentes para uma economia de subsistência. Esta população continuou, entretanto, disponível para a produção, principalmente através do mecanismo de aviamento.

Esse balanço não poderia ser encerrado sem uma menção à ampliação territorial do país. Não se trata pura e simplesmente de uma ampliação do território, mas de um aumento do fundo de terras, ou seja, de riqueza.

Conta Augusto Cespedes ${ }^{31}$ que em 1867 o Brasil "ganhou mais de $100.000 \mathrm{~km}^{2}$ de território em relação aos tratados de 1750 e 1777 ”. No

\footnotetext{
${ }^{30}$ Com o fim do ciclo e a consequente desorganização da economia do seringal, a mão de obra indígena foi utilizada em setores anteriormente desprezados. "Foi assim que os Tucuna voltaram a fazer sua agricultura, inclusive incentivados pelo proprietário da gleba. Incentivados foram também para a manufaturação da farinha, como para a caça de bichos de pêlo comerciável ou para a obtenção de fibras de tucum”. OLIVEIRA, Roberto C de, op. cit., p. 13. O que indica a variedade de formas de readequação no uso da mão de obra anteriormente lotada na extração do látex.

${ }^{31}$ CESPEDES, A., El Dictador Suicida (40 Años de Historia Boliviana), Librería y Editorial "Juventud", La Paz, 1968, 2a ed., pp. 19-25.
} 
entanto, "o tratado havia deixado dentro da Bolívia o Território do Acre, do qual o Brasil se lembrou quando a cotação da borracha obteve altos índices, iniciando uma política de penetração mediante imigrantes e empresários brasileiros, aproveitando sua privilegiada situação de dono da desembocadura dos rios por onde saía a goma boliviana". A essa penetração brasileira, a Bolívia tenta responder com a concessão do Acre a uma organização norteamericana, o "Bolivian Syndicate", para que explorasse o látex e colonizasse a região; a concessão, obviamente, procurava neutralizar a ofensiva brasileira. Cespedes assevera que "bem se vê agora que Aramayo (capitalista mineiro e ministro boliviano) rechaçava o imperialismo em seu sentido de invasão ou de ocupação armada (brasileiro), mas admitia-o em seus domínios em suas formas financeiras e contratuais (norte-americanas)".

O Brasil, ao mesmo tempo que penetrava no Acre com Plácido de Castro à frente, subornava os cavalheiros norte-americanos do "Bolivian Syndicate" (entre os quais achava-se um Roosevelt), mediante a quantia de 110.000 libras. ${ }^{32}$

Cespedes descreve resumidamente as idas e vindas da luta diplomática e militar e conclui dizendo que o governo boliviano, pressionado pelas ameaças brasileiras, submeteu-se ao acordo. A proposição da compra do território foi aceita e reconhecida a soberania brasileira sobre o Acre $\left(190.000 \mathrm{~km}^{2}\right)$ mediante a indenização de 2 milhões de libras (Tratado de Petrópolis, 1903). "Ditos milhões significavam menos que os ingressos que obtinha o governo do Brasil em um só ano pela goma desse território".

Demograficamente, foi o Acre a área da Região norte que mais recebeu imigrantes ligados à extração do látex. Reflexo disso estampa a Tabela I, no ano 1940: quase $20 \%$ de sua população procedem dos Estados nordestinos.

${ }^{32}$ A. P. Jacobina possui uma visão diferente da ação de Plácido de Castro: “Assim, as páginas históricas vividas por P. de Castro, um caudilho contra o imperialismo, arrematavam bem os esforços para o arredondamento de nossa posição, inconteste, na Amazônia brasileira. A chamada revolução acriana foi, sem dúvida, um gesto autêntico do espírito de brasilidade de nosso povo. Quando o truste internacional, através do contrato de arrendamento, pretendeu espoliar-nos, provocou um levante em massa". Revista Civilização Brasileira, (17), 31, jan./fev., 1968.
Por fim, cabe observar que a queda da exploração do látex, que colheu a vida de milhares de trabalhadores, ${ }^{33}$ não se explica apenas pela vitoriosa concorrência da borracha oriental, mas deve-se também a fatores internos, como bem assinalaram Prado e Capelato: "Os representantes políticos da Amazônia nunca conseguiram consolidar uma política de defesa da borracha. Além disso, os lucros auferidos na região foram canalizados para o consumo, não concorrendo para a transformação das condições existentes". ${ }^{34}$

\section{Frentes pioneiras: castanha, garimpagem e pecuária}

O retorno à economia de subsistência no período 1920-40 foi parcial e localizável (áreas extrativas de látex), pois a extração da castanha conheceu uma fase de expansão. Sem embargo, convém ter presente que três quartos da população em 1940 eram da zona rural e concentravam-se no Pará, área natural da castanha.

Já no século XVIII a castanha-do-pará era exportada para a Europa. Na segunda e terceira décadas do século XIX obtinha boa cotação naquele mercado. ${ }^{35}$ Tudo leva a crer que a extração florestal desse recurso foi interrompida com o ciclo da borracha, pois com a decadência desse, passou a ter relativa importância. A castanha torna-se, por algum tempo, o principal produto de exportação da Amazônia, lembra Darcy Ribeiro; ela "cresce em terras altas onde não vinga a seringueira, exatamente naqueles ermos onde o índio, expulso das terras baixas, fora se acoitar e de onde iria ser desalojado pela nova onda invasora" ${ }^{36}$

Otávio Velho diz que a infraestrutura da borracha foi toda orientada para a castanha, o que permitiu à área recuperar-se da crise e evitar o êxodo

\footnotetext{
${ }^{33}$ Para ter-se uma ideia da violência no uso da força de trabalho na economia da borracha, basta registrar as revelações do Livro Azul inglês sobre as práticas do Peruvian Amazon Co. Ltd., sediada em Putumayo, no vizinho país. Entre, aproximadamente, 1900 e 1910, aquela empresa lançou umas 4.000 toneladas de borracha no mercado londrino; no mesmo período, morreram 30.000 indígenas e 10 mil tomaram-se inválidos. Apud Luxemburgo, Rosa, A Acumulação do Capital. Zahar Ed., Rio de Janeiro, 1970, Cap. XXVI, p. 308, nota 5.

${ }^{34}$ PRADO, M. L. C. e CAPELATO, Maria H. R., op. cit., p. 307.

${ }^{35}$ BASA, op. cit., p. 148.

${ }^{36}$ RIBEIRO, Darcy, op. cit., p. 29.
} 
da mão de obra. ${ }^{37}$ Deve-se observar que a parte da área que produz castanha não abrange toda a área produtiva de borracha, bem como não é a área mais importante de extração do látex. Por outro lado, tentando traçar um' quadro geral da região na época, podemos acrescentar que, na década dos 30 , foi tentada uma produção agrícola mercantil de arroz, juta e pimenta, mediante colonos japoneses, que resultou em fracasso. Demais, a população ligada à exploração de castanha complementava seus meios de vida, nas entressafras, com a garimpagem que, em épocas de recessão, apresentava-se mesmo como uma das alternativas para a economia local.

No que concerne à pecuária, no período de 1920 e 40, ela estava concentrada na ilha de Marajó e atendia basicamente ao mercado de Manaus e de Belém. ${ }^{38}$ Quanto à pecuária paraense, podemos dizer que é quase totalmente importada do Maranhão e de Goiás, excetuando-se, é óbvio, a da ilha de Marajó.

Deve-se notar, como fez Guilherme Velho, que tanto a agricultura como a pecuária, nessa época, têm um caráter intersticial frente à extração, quer dizer, quase nada contam em termos econômicos de mercado. Essa situação faz parte de outra, mais geral: as frentes que vão Amazônia adentro provêem a si mesmas dos meios de subsistência. Este quadro sublinha a quarta característica anteriormente apontada no balanço do ciclo da borracha: a frágil diferenciação do trabalho social; esta, quando existe, restringe-se aos dois grandes núcleos urbanos.

Em termos demográficos, a tabela a seguir dá-nos um balanço sucinto. Das 1462 mil pessoas, 65\% estavam no Pará, algo em torno de $30 \%$ no Amazonas, o restante no Acre (5\%). Este, área de extração do látex por excelência, apresenta a maior porcentagem de pessoas não nascidas em seus limites, um pouco mais de 30\%; os outros Estados têm porcentagens bem menores. A proveniência dos não nascidos na Região norte, em 1940,

${ }^{37}$ VELHO, Otávio Guilherme, Frentes de Expansão e Estrutura Agrária: Estudo do Processo de Penetração numa Área da Transamazônica, Ed. Zahar, Rio de Janeiro, 1972. À época, o sistema extrativo fundava-se na livre propriedade de terra (eram terras devolutas) mas era sob o controle do sistema de aviamento, que inclui o do barracão.

${ }^{38}$ A criação de gado teve início na Região norte nos campos ribeirinhos do Arari (ilha de Marajó), em 1680. No século XVIII a criação desenvolve-se no baixo e médio Amazonas e no atual Território de Roraima e no Território do Amapá. (Em 1920 o número de cabeças estava por volta de 1300 mil; em 1940, 1500 mil.) Consulte-se o Cap. XI, Pecuária Extensiva, in Grande Região norte, op. cit., pp. 287-300. mostra o Estado do Ceará como principal área fornecedora, com mais de 65 mil pessoas, em sua maioria (oriundos do Ceará relativamente à população de cada Unidade da Federação) localizadas no Acre.

I - População das unidades da federação da região norte, segundo o lugar de nascimento - 1940

\begin{tabular}{|l|c|c|c|c|c|c|}
\hline \multirow{2}{*}{ Lugar de nascimento } & \multicolumn{2}{|c|}{ Acre } & \multicolumn{2}{c|}{ Amazonas } & \multicolumn{2}{c|}{ Pará } \\
\cline { 2 - 7 } & Número & $\%$ & Número & $\%$ & Número & $\%$ \\
\hline Mesma Unidade da Federação & 55643 & 69,8 & 376370 & 86,0 & 855966 & 90,5 \\
\hline Outras U. da F. da R. norte & 5831 & 7,3 & 15930 & 3,6 & 8146 & 0,9 \\
\hline Ceará & 12319 & 15,4 & 23077 & 5,3 & 30786 & 3,3 \\
\hline Outros Estados nordestinos * & 4286 & 5,4 & 11469 & 2,6 & 31673 & 3,4 \\
\hline Outros Estados Brasileiros & 441 & 0,6 & 3587 & 0,8 & 6835 & 0,7 \\
\hline Países estrangeiros & 1236 & 1,5 & 7441 & 1,7 & 11074 & 1,2 \\
\hline Nacionalidade não declarada & 12 & 0,0 & 134 & 0,0 & 164 & 0,0 \\
\hline Total & 79768 & 100,0 & 438008 & 100,0 & 944644 & 100,0 \\
\hline
\end{tabular}

Fonte: Censo Demográfico de 1940

* Principais Estados: 1443 RN ; 2732 MA ; 12755 MA

Obs.: As populações dos Territórios de Roraima, Amapá e Rondônia atuais estão incluídas (1940), respectivamente, nas dos Estados do Amazonas, Pará e Mato Grosso.

Assim como na época do ciclo da borracha, ainda em 1940 a quase totalidade dos imigrantes da Região norte provém do nordeste. Por outro lado, há que se notar que, por volta de 1910, mais de $70 \%$ da população amazônica eram de origem imigrante (praticamente 1 milhão em 1400 mil), agora, em 1940, quase $90 \%$ da população têm suas raízes na região. 